W stużbie tradycji i odnowy liturgicznej. 50 lat Instytutu Liturgicznego w Krakowie (1968-2018), red. P. Nowakowski, J. Mieczkowski, Kraków 2019, s. 153-159.

ISBN 978-83-7438-849-8 (wersja drukowana), ISBN 978-83-7438-850-4 (wersja online) DOI:http://dx.doi.org/10.15633/9788374388504.13

Marcel Mojzeš

\title{
Dôležitost' teologického a duchovného prístupu v procese liturgickej obnovy v Gréckokatolíckej cirkvi na Slovensku
}

Okrúhle jubileum, zvlášt ak ide o 50 rokov v živote človeka, je vždy príležitostou pristavit’ sa a urobit reflexiu nad tým, ako vyzeral doterajší spôsob života a zároveň zozbierat’ sily a zamerat’ sa v d’alších rokoch na to, čo je naozaj podstatné. Ďakujem organizátorom tohto krásneho jubilejného sympózia za pozvanie a za to, že pri príležitosti 50. výročia Liturgického inštitútu v Krakove vytvorili túto jedinečnú možnost’ stretnút sa a urobił reflexiu nad tým, ako vyzeral doterajší spôsob života jednotlivých liturgických centier a zároveň zozbierat’ sily a spoločne sa zamerat’ sa to, čo je naozaj podstatné.

Naša Gréckokatolícka cirkev na Slovensku prežíva v tomto roku viaceré jubileá. 1150 rokov od schválenia staroslovienskych liturgických kníh, ked’ v roku 868 pápež Hadrián II. v rímskej bazilike Santa Maria Maggiore prijal z rúk sv. Cyrila a Metoda bohoslužobné knihy preložené do staroslovienčiny, požehnal ich a položil na oltár. Ďalej 200 rokov od zriadenia Prešovskej eparchie, ktorá vznikla v roku 1818 vyčlenením z Mukačevskej 
eparchie a napokon 50 rokov od obnovenia činnosti Gréckokatolíckej cirkvi v bývalom Československu v roku 1968 po násilnej 18 ročnej likvidácii komunistickým režimom.

Proces plnej obnovy činnosti našej cirkvi však začal až po páde komunizmu začiatkom 9o. rokov minulého storočia. Súčastou tohto procesu je aj obnova východného liturgického a duchovného dedičstva. Je však dôležité zdôraznit', že v snahe byt’ verní usmerneniam pápežov a Druhého vatikánskeho koncilu pri 'návrate $\mathrm{k}$ dedičstvu otcov ${ }^{1}$ je nevyhnutné neostat' len kdesi na povrchu pri čisto obradových, schematických, či estetických otázkach, ale venovat’ dostatočnú pozornost’ práve prehíbeniu teologického a duchovného prístupu k liturgii i k celej obnove života cirkvi.

Je iste pochopitel'né, že práve v obdobiach, ked' v dejinách začalo slabnút’ poznanie tradície, vznikali isté schémy, ktoré mali pomôct’ túto tradíciu uchovat'. Klasickým príkladom je vznik tzv. podlinnikov pri tvorbe ikon. Samotná liturgia je na Východe vnímaná ako ikona Božieho královstva, preto môžeme o to viac tento príklad použit’.

Podla Pavla Evdokimova:

Zastavenie sa samotného elánu ikonopisectva od 17. storočia nesie vel'kú zodpovednost’ za osud moderného umenia [...] preto je potrebné viac ako inokedy znovuobjavit tvorivú moc dávnych ikonopiscov a vyjstł z nehybnosti umenia tých, čo kopírujú2.

Otcovia Špidlík a Rupnik hovoria, že 'Kto kopíruje, sústred'uje sa len na techniku, aby reprodukoval formálnu skutočnost'. Chýba tu teda cirkevný, komunikatívny rozmer ${ }^{3}$. Cirkev je Kristovo telo a ako bolo uvedené na blogu jedného ukrajinského blogera: Slovo sa telom stalo, a nie Slovo sa s textom stalo. Aj pri Biblii hovoríme, že čítame Božie slovo, a nie Boží text. Text len zachytáva slovo. No slovo je viac ako text. Je prostriedkom komunikácie medzi osobami, dokonca pri Bohu platí, že Boh je Slovo.

Môžeme teda povedat', že aj pri procese liturgickej obnovy nestačí len kopírovat', len sa sústredit’ na techniku - napríklad len na text či na zacho-

1 Orientalium Ecclesiarum, 6.

2 Porov. P. Evdokimov, L'art Moderne ou la Sophia Désaffectée, http://www.myriobiblos.gr/ texts/french/contacts_evdokimov_moderne.html (20.09.2018).

3 Porov. T. Špidlík, M. Rupnik, Viera vo svetle ikon, Bratislava 2004. 
vávanie rubrík, ale potrebujeme 'viac ako inokedy znovuobjavit tvorivú moc dávnych umelcov'. Teda potrebujeme nielen ars celebrandi, ale ars vivendi.

Emeritný Svätý otec Benedikt XVI. rozdelil posynodálnu apoštolskú exhortáciu o Eucharistii Sacramentum caritatis na tri časti: mysterium fidei, mysterium celebrandi a mysterium vivendi.

Bol som užasnutý, ked’ som čítal oficiálnu správu o tom, ako pred rokom, pri príležitosti 9o. narodenín emeritného pápeža sa s ním stretol metropolita Hilarion Alfejev a ako dar mu venoval ruský preklad jeho vyše 800 stranového diela Teologia della liturgia, vydaný vo vydavatel'stve Moskovského patriarchátu Bol som užasnutý z dvoch vecí: 1. že si ruskí pravoslávni dali tú námahu a preložili významné liturgicko-teologické dielo emeritného pápeža a 2. zo slov samotného emeritného pápeža, ktorý pri prijatí daru vrúcne pod’akoval a vyjadril želanie, nech táto kniha je pomocou pre pravoslávnych krest̉anov v Rusku pre lepšie porozumenie liturgii. Aká odvaha! No ak sa čerpá z autentickej tradície, niet sa čoho bát a môžeme si takto podobne jedni druhým slúžit.

Vrátme sa k ikonám a k tvorivej moci dávnych umelcov. Evdokimov d’alej odvážne pokračuje:

Príručky ikonopisectva slúžia len ako dokumentácia. Začali sa hromadne šírit až v 16.-18. storočí, kedy začínalo slabnút poznanie Tradície. To, čo je podstatné na ikonopise, sa nachádza v priamom učení a ústnom odovzdávaní od učitel’a (majstra) k žiakom [...]. Majstri nasledovali tradíciu úplne prirodzeným spôsobom, bez toho, že by si toho boli aj vedomí a bez toho, aby túto skutočnoste cítili ako prekážku ich tvorivosti. Vari možno povedat', že umelec je otrokom svojho modelu? [...] Tradičným formám vtláčali celkom osobný charakter a tak ostávali verní samotnému duchu tradície, ktorá je vždy prýštiacim životom, tvorivým vývojom, víziou toho, čo nevidno dva razy.

Klasickým príkladom ikonopisca, ktorý tradičným formám vtláčal celkom osobný charakter a tak ostával verní samotnému duchu tradície, je Andrej Rublev. Jeho ikona Najsvätejšej Trojice nadobudla taký význam, že v Ruskej pravoslávnej cirkvi sa stala priam 'prototypom' pre vôbec akékol'vek zobrazovanie Najsvätejšej Trojice.

'Tradičným formám vtláčat' celkom osobný charakter a tak ostávat' verní samotnému duchu tradície, ktorá je vždy prýštiacim životom, tvorivým vývojom’ - to je dôležitý princíp aj pre liturgickú obnovu. 
Ruská pravoslávna cirkev už pred 100 rokmi (v mnohom, čo sa týka liturgie, vo vnútrocirkevnej diskusii predbehli aj Druhý vatikánsky koncil, ako tvrdí prof. Suttner) diskutovala o realizácii tzv. liturgickej kreativity (liturgičeskoje tvorčestvo). Boli to pritom l'udia, ktorí nekritizovali liturgiu naprázdno, ale naopak, milovali ju a ukazovali, že je možný jej organický vývoj. Ako hovorí Svätý Otec František, ak sme

naštepení a zakorenení v Kristovi a necháme sa viest’ Svätým Duchom, všetko je možné s prirodzeným nadaním a kreativitou. (EG 94)

Gréckokatolíci na Slovensku pred 50-imi rokmi, pri príležitosti 1100. Výročia zosnutia svätého Konštantína - Cyrila (1969) formulovali Rozhodnutie obnovit Gréckokatolícku cirkev vo svetle Druhého vatikánskeho koncilu, kde sa okrem oiného hovorí, že 'budú rozlišovat' živú tradíciu od zväzujúcej tradičnosti'.

Svätý Ján Pavol II. pri definovaní pojmu Tradícia vo svojom apoštolskom liste Orientale Lumen opakovane používa prívlastok 'živá':

Tradícia je dedičstvo Kristovej Cirkvi, živá pamiatka na Vzkrieseného, ktorého stretli apoštoli, o ktorom vydali svedectvo a ktorého živú spomienku odovzdali vkladaním rúk svojim nástupcom v neprerušenej línii, zaručenej apoštolskou postupnostou až k biskupom dneška. Tradícia sa skladá z historického a kultúrneho bohatstva každej cirkvi, ktoré sa v nej utváralo na základe svedectva mučeníkov, otcov a svätcov, ako aj zo živej viery všetkých krest̉anov počas stáročí až po dnešok. Nejde tu o nemenné opakovanie formúl, ale o dedičstvo, ktoré v sebe chráni živé jadro pôvodného ohlasovania. Tradícia chráni Cirkev pred nebezpečenstvom zhromažd'ovania premenlivých názorov a zaručuje jej istotu a trvácnost'. Ak sa spôsoby a zvyky vlastné každej cirkvi chápu ako číra nehybnost', zaiste je tu riziko, že sa tradícii takto odníme ten charakter živej skutočnosti, ktorá sa rozvíja a rastie, a ktorý jej Duch zaručuje práve nato, aby sa prihovárala lud’om v každom čase. Tak ako Písmo rastie s tým, kto ho číta, tak aj každý iný prvok živého dedičstva Cirkvi rastie $\mathrm{v}$ chápaní veriacich a vo viere a v kontinuite sa obohacuje o nové prínosy. Jedine nábožné asimilovanie v poslušnosti viery toho, čo Cirkev nazýva 'tradíciou', jej umožní inkarnovat’ sa v rozličných historicko-kultúrnych situáciách a podmienkach. Tradícia nespočíva nikdy v čírej nostalgii za vecami alebo formami minulosti, alebo v oplakávaní stratených privilégií, ale je živou spomienkou Nevesty, ktorá sa uchováva večne mladá skrze lásku, ktorá v nej prebýva. (OL 8) 
Skutočné krestanstvo, skutočný život Cirkvi znamená žit život Ježiša Krista skrze dar Svätého Ducha, a nie vytvárat novú idelógiu, odtrhnutú od života ${ }^{4}$. Vel'kou výzvou je teda integrovat’ dnešný život, život dnešných rodín do liturgie. 'Liturgia semper pro hominibus [...] non homines pro liturgia ${ }^{5}$ ako povedal kardinál Giovanni Battista Montini, neskorší svätý pápež Pavol VI. na Druhom vatikánskom koncile.

Teologický a duchovný prístup k liturgii teda dáva na prvé miesto život, v prvom rade Boží život, ktorý sa túži vtelit do života človeka a zbožštit ho. Teologický prístup znamená vnímat' a uvádzat’ seba i druhých do toho, ako Boh hovorí a koná v liturgii. Duchovné v krest’anskom zmysle a teda i v liturgii je všetko to, čo pôsobením Svätého Ducha človeku hovorí o Bohu, orientuje ho na Boha a napokon ho s Ním zjednocuje.

$\mathrm{V}$ našom úsilí totiž potrebujeme pomôct’ dnešnému človeku nájst’ $\mathrm{v}$ liturgii naozaj prameň a vrchol celého krestanského života (SC). Ako nájst’ prameň a vrchol? Ak by sme tento obraz preniesli do hôr, napríklad do Vysokých Tatier, ktoré spájajú naše dve krásne krajiny, Pol’sko a Slovensko a ktoré mal tak rád aj svätý Ján Pavol II., môžme povedat', že kdesi uprostred, na ceste medzi prameňom a vrcholom stolí malé jazierko - pleso. Pri osobitnej audiencii, ktorú udelil Svätý Otec František gréckokatolíkom zo Slovenska 6. októbra tohto roku v Ríme, začal svoj príhovor slovami svätého Jána Pavla II., ktoré povedal tento vel'ký slovanský pápež gréckokatolíkom pri svojej návšteve Prešova v roku 1995, ked’ si vzal na prirovnanie krásny obraz okolitej prírody, aby opísal identitu a poslanie gréckokatolíckych komunít:

V priezračných vodách sa zrkadlí majestátna výška končiarov. Tento kraj jedinečný v rozmanitosti stvorenia hovorí nám o kráse a dobrote Stvoritela. Od južných svahov Tatier až po zemplínsku rovinu už stáročia žijú popri bratoch a sestrách latinského obradu spoločenstvá východného obradu. Aj ony sú ako malé jazierka-plesá povolané predstavovat’ priezračnú a žiarivú Božiu dobrotu ${ }^{6}$.

4 Porov. M. I. Rupnik, Secondo lo Spirito. La teologia spirituale in cammino con la Chiesa di papa Francesco, Città del Vaticano 2018, s. 14-16.

5 Acta Synodalia, 1/1, s. 315.

6 Príhovor pápeža Františka slovenským gréckokatolíkom, http://www.grkatpo.sk/?spravy\&id=2941 (20.09.2018). 
Pleso stojí uprostred cesty od prameňa $\mathrm{k}$ vrcholu, pričom vrchol sa v ňom odráža, ako obraz priezračnej a žiarivej Božej dobroty. Pri plese si môže človek oddýchnut', občerstvit’ sa vodou z Prameňa a načerpat' sily v snahe vystúpit na Vrchol. No ako hovorí kardinál Špidlík pri interpretácii ikony Narodenia Pána, od okamihu Vtelenia Božieho Syna už človek v snahe stretnút Boha nemusí vystupovat’ na vrchol hory, ako to bolo v predkrest’anských náboženstvách. Lebo totiž sám Boh zostúpil. Liturgia a cirkev je tak povolaná predstavovat priezračnú a žiarivú dobrotu tohto Boha, ktorý zostúpil. Najlepšie sa končiare odrážajú vo vode plesa, ak je pleso čisté, priezračné a pokojné. Svätý Ján Pavol II. nám všetkým naznačil a pripomenul, že táto čistota, priezračnost’ a pokoj cirkvi i liturgie, ktorá život cirkvi vyjadruje, sú vlastne len účastou na čistote, priezračnosti a pokoji Boha, ktorý sa stal človekom, aby nás spasil. Jemu patrí všetka sláva a čest’ a poklona Otcu i Synu i Svätému Duchu teraz i vždycky i na veky vekov. Amen.

\section{Streszczenie}

Znaczenie podejścia teologicznego $i$ duchowego w procesie odnowy liturgicznej w Kościele greckokatolickim na Słowacji

Po upadku komunizmu od lat 9o. XX wieku aż po dziś greckokatolicki Kościół na Słowacji jest $\mathrm{w}$ procesie odnowy wschodniego dziedzictwa liturgicznego i duchowego. $\mathrm{W}$ tym procesie możemy się spotkać także z powierzchownym i rytualistycznym podejściem do liturgii, w którym niewystarczająco zwraca się uwagę na teologiczny i duchowy wymiar liturgii.

Kilka lat temu pewne słowackie greckokatolickie zgromadzenie sióstr redemptorystek, które odbyły formację monastyczną w Polsce w Bielsku-Białej w tradycji łacińskiej (zachodniej), poprosiło mnie i jeszcze kilku innych księży, abyśmy wprowadzili je do liturgii i duchowości wschodniej. Te siostry mieszkają dzisiaj w pięknym klasztorze koło Vranov na Słowacji, gdzie zbudowały kaplicę w stylu bizantyjskim, z ikonostasem, i gdzie modlą się według liturgii bizantyjskiej, włącznie $\mathrm{z}$ liturgią godzin.

Pamiętam jednak do dzisiaj pytanie jednej z sióstr: „Dlaczego papież chce, byśmy były w rycie wschodnim?". To bardzo dobre pytanie. Myślę, że my, grekokatoli- 
cy, nie tylko na Słowacji, powinniśmy mieć obrządek wschodni nie ze względu na naszych prawosławnych braci i siostry ani też nie ze względów ekumenicznych, estetycznych czy z powodu zewnętrznych rytów.

Jeden z wielkich ekspertów liturgii bizantyjskiej i mój były profesor Robert Taft SJ w swojej słynnej książce zatytułowanej Katolicyzm obrządku wschodniego - jego dziedzictwo i powołanie pisał, że katolicy wschodni wiedzą, że najważniejszą kwestią nie jest wierność Wschodowi czy Zachodowi, ale wierność Chrystusowi. Napisał te słowa podczas trwania soboru watykańskiego II, kiedy nasi biskupi, kapłani i wierni dawali świadectwo swojej wiary Chrystusowi i Jego Kościołowi, cierpiąc w czasach komunizmu.

Teraz, kiedy zostaliśmy wezwani do odnowy nie tylko naszej wschodniej tożsamości, ale jednocześnie jesteśmy nieustannie wzywani przez Ducha Świętego do odnowy naszej chrześcijańskiej tożsamości, nie powinniśmy pozostawać jedynie na powierzchownym poziomie estetyki czy rytualizmu. Powinniśmy odkrywać nasze wschodnie dziedzictwo pod kątem teologicznym i duchowym. Tylko wtedy możemy być prawdziwie wschodni i katoliccy.

Idąc w ślady wielkich ekspertów teologii i duchowości liturgicznej, takich jak na przykład Aleksander Schmemann, Tomaš Špidlik i jego uczniowie, papież senior Józef Ratzinger i inni, także z waszego Instytutu Liturgicznego, powinniśmy cierpliwie odkrywać ponownie teologiczny i duchowy sens liturgii. To znaczy, jak Bóg przemawia i działa podczas liturgii w sercach i życiu wierzących. Takie podejście do liturgii jest i będzie naszą najlepszą posługą dla liturgii, dla Kościoła i samego Boga. 
